DOI: $10.24193 /$ tras.61E.8

Published First Online: 10/27/2020

\section{NON-COMPLIANCE \\ IN PUBLIC PROCUREMENT \\ - COMPARATIVE STUDY \\ UNDER EU LAW}

\author{
Tünde TÁTRAI \\ Gyöngyi VÖRÖSMARTY
}

Tünde TÁTRAI (corresponding author)

Ph.D., Professor, Department of Logistics

and Supply Chain Management,

Corvinus University of Budapest, Budapest, Hungary

E-mail: tunde.tatrai@uni-corvinus.hu

Tel.: 0036-1-482.52.61

\section{Gyöngyi VÖRÖSMARTY}

Ph.D., Associate professor, Department of Logistics and Supply Chain Management,

Corvinus University of Budapest, Budapest, Hungary

E-mail: gyongyi.vorosmarty@uni-corvinus.hu

\title{
Abstract
}

There is an expectation towards public policy to ensure efficiency in public procurement (manage public spending properly), ensure accountability and support the social, environmental and other economic and political goals. Increasingly complex regulation raises the question of whether its complexity helps or rather hinders the efficient spending of public money. This paper aims to contribute to the discussion going on about efficiency in public procurement. It investigates non-compliance in public procurement with the aim of revealing types of non-compliance and to structure knowledge on the effects of the remedy system to non-compliance.

Keywords: public procurement, non-compliance, EU law, efficiency, public policy. 


\section{Introduction}

In the context of public policy, public procurement related research focuses mainly on affected groups such as SMEs or on sustainability issues (Preuss, 2011; Flynn and Davis, 2016; Testa et al., 2016; Flynn, 2018). Numerous public policy papers also highlight the relationship between public procurement and innovation (Rolfstam, 2009; Vecchiato and Roveda, 2014). In addition to these important topics, efficiency of public procurement in the public policy context is less frequently addressed. This study aims to contribute to the public policy discussion by highlighting this aspect of the public procurement policy making. It will investigate non-compliance in public procurement with the aim of revealing types of non-compliance and to structure the knowledge on the effects of the remedy system to non-compliance.

Public procurement officials, while accomplishing their jobs to procure goods and services that satisfy the needs of their organisations, are bound by laws, procedures and regulations. There is an expectation towards them to ensure efficiency (manage public spending properly), ensure accountability and support the social, environmental and other economic and political goals. These expectations, in general, are common to all procurement systems. However, the effect of the constantly growing regulations has led to a debate among scholars and practitioners who were concerned with the impact on public procurement performance as they seek to comply with rules (Kassel, 2008).

The goal of the paper is to investigate the reasons for and types of non-compliance in public procurement while connecting the realms of public procurement and public policy which are rarely addressed together in literature. The structure of the paper will be the following: after the literature review we develop four dimensions to investigate the reasons for non-compliance in public procurement. Comparing the interviews' results of nine EU countries, our conclusions revealed that a procurement-friendly set of institutions shall be well prepared, have experience, and be reliable, efficient, cheap and flexible.

\section{Literature review}

Research on public procurement was devoted to examining the potential causes of non-compliance to ensure that risks were avoided. It was frequently hypothesised that the complicated regulations pose high risks of inefficient ways of spending funds (these rules increase transaction costs for buyers and suppliers) and they raise risks in terms of achieving public goals (Hawkins and Muir, 2014). Gelderman, Ghijsen and Brugman (2006) identified four groups of potential reasons for non-compliance. Their empirical findings related to an EU (Danish) sample indicated that familiarity in purchasing with the rules and organizational incentives has a positive impact on compliance, while alleged inefficiency of the EU Public Procurement Directives (hereafter EU PP Directives, namely Directive 2014/23/EU, Directive 2014/24/EU and Directive $2014 / 25 / \mathrm{EU}$ ), and the expected supplier resistance seem not to influence compliance 
with the directives. The work of Brammer and Walker (2011) extended this investigation to sustainable procurement. Their results about the main facilitators of and barriers to engagement with sustainable procurement in the public sector show that if government policy and legislation is supportive of sustainable purchasing, public sector organisations are more likely to implement sustainable purchasing. Investigating US practice, Hawkins and Muir (2014) highlighted that effectiveness of public procurement depends on mastery of vast knowledge (especially the accumulated knowledge of the individual agent), and it also promotes compliance with the laws.

In addition to cost-effectiveness and legal compliance, the need for innovation also appears (Heijboer and Telgen, 2002; Brammer and Walker, 2011). Innovation (just as in the private business sphere) should be a very important issue in the public sector as well, since this would provide opportunities for achieving the most complex business results and achieving the most innovative goals and promote the innovativeness of suppliers.

As this brief summary suggests, literature addresses the issue of compliance in terms of barriers and facilitators. It has also been addressed which EU PP Directives are most sensitive to non-compliance (Gelderman, Ghijsen and Schoonen, 2010). However, according to our knowledge, only limited information exists about the actual characteristics of non-compliance.

The risks of non-compliance in procurement and public procurement greatly differ from one another (Karjalainen, Kemppainen and Van Raaij, 2009). As public procurement in the European Union is based on a uniform set of rules, an exceedingly great deal of experience has been accumulated about the risks of non-compliance in the public procurement market. The difference is largely in the fact that expressly from the viewpoint of the public purchaser, the contracting authority needs to comply with rules other than the internal ones of a company. The internal rules of a company may be exceedingly administrative and lengthy, yet they can be changed and they serve first and foremost the interests of the purchaser. In the profit-oriented sphere, the purchaser needs to worry about sanctions not in the course of the procurement process, but mostly in the course of performance. A purchaser is affected by the risk of non-compliance with the corporate internal rules primarily as a person because if she/he fails to comply with the corporate internal rules, she/he may be called to account. The organisation itself is entitled to interpret internal corporate rules, which means that so long as the competition rules of the Civil Code and, of course, competition law are complied with, the risk of not following the company's own procedural rules poses little threat. Naturally, one of the reasons for this in the profit-oriented sphere may be that market actors are not fully informed of the procedure and they are unable to enforce their interests the same way as in public procurement, where in many cases there is a dedicated forum of legal remedies addressing their problems. Of course, economic actors are always restrained knowing that if they harm the entity inviting bids, it will no longer be willing to contract with them later on. This restraining force is less enforced in public procurement because if a bidder meets 
the conditions of the publicly announced procedures, the contracting authority has little possibility to blacklist them and not to contract with them as in the non-public procurement market.

Our assumption is that the approach, innovativeness and, accordingly, the ability of the purchaser to assume risks is influenced by the extent to which the system of legal remedies is prepared to solve the legal problems arising in the course of the procurement procedure. Similarly, if the purchaser is aware, he may be influenced by the knowledge that financing legal remedies is expensive, thus few can afford it. Another important factor is the length and efficiency of such a legal dispute, because the purchaser may suffer the gravest damage, if she/he cannot continue procurement, she/ he cannot meet the demands because of waiting for the results of the legal remedy procedure. There are a number of other factors, which may affect that approach and decisions of the public purchaser in the course of the procurement procedure.

The innovativeness of the public purchaser may be manifested in the choice of the type of the procedure, in drafting the selection criteria, in delineating the technical content, in working out the content of the contract and in developing the set of contract award criteria. In our case, we would regard it as innovative if the purchaser chose the innovation partnership procedure, for instance, where the purchaser and his partners engage in innovation jointly and economic actors compete only thereafter. Similarly, the use of the eco label among the contract award criteria, or taking the criteria of environmental protection into account when defining the technical content, whether in setting the selection and contract award criteria, could be innovative. Paying particular attention to social criteria in the course of contract performance with a view to preventing child labour being employed by any actor across the supply chain could also be innovative.

Our point of departure is the assumption that the legal remedy systems of public procurement may impact in many ways whether economic actors make use of their rights and whether they initiate legal remedy procedures. In the course of our research, we do not study the reliability and independence of the fora of legal remedy, but the implementation of the same EU PP Directive-based regulatory environment in nine European Union Member States under study.

\section{Methodology}

Our goal is to develop a categorization of types of non-compliance, taking into account national remedies and the legal environment. Our assumption was that the main characteristics of the remedy system influence the approach, innovativeness and ability of the purchaser to assume risks. Particular attention is paid to the application of green and social considerations in public procurement, which is one of the most important proofs of the innovative attitude of public purchasers.

To assess the actual non-compliance problems, we conducted in-depth interviews with 9 national experts from the European Union. 
We began our research with the exploration of the systems of legal remedy, studying these systems in nine EU Member States. National experts answered our questions (see the interview guide in Annex 1). Following the interview template was obligatory for all the interviewees in order to compare their answers. The experts were asked to answer all nine questions and to seek typical legal cases and national examples. The experts were lawyers, who were selected primarily because of their knowledge of the legal background. Our intention was to cover as much as possible of the European Union in order to discover different characteristics of different regions. In every case, there were experts involved in public procurement who were personally interviewed following the completion of our interview template. The countries under study included Austria, Germany, France, Finland, Sweden, Poland, Romania, Italy, and Hungary.

Based on the experts' answers, we group the countries and summarize for each group how compliance risk combats innovativeness based on national practices. The experts presented the characteristics of the systems for legal remedy on the basis of which we can draw our conclusions using a measurement system and identify the criteria that influence the non-compliance decisions of public purchasers.

\section{National remedy systems and their characteristics}

The literature review revealed that only a few research addresses the types and forms of non-compliant purchasing behaviour. However, a number of papers refer to how the knowledge and complexity of procurement processes may effect compliance of activities.

Having become acquainted with the systems and procedures of legal remedy, we distinguished four important types of non-compliance leading to the assumption of higher risks on the part of the public purchaser:

1. Capability of the remedy system to comprehend procurement problems;

2. The fee and other costs of the remedy procedure;

3. Length and efficiency of the remedy procedure;

4. Other characteristics of procedural law.

The types of non-compliance were determined based on the logic of individual national remedy systems. The interview template aimed to discover the characteristics of national remedy systems. The answers of the interviewees highlighted the most important reasons of non-compliance in their specific country. The nine topics of the interview template allowed us to organize the opinions around the four dimensions. Next to the first three topics (capability, cost, efficiency), the fourth dimension flexibly involved other experiences of national experts.

Behind the four dimensions there was the underlying assumption that if the public purchaser believes that there is no real danger of legal remedy, he will be bold to make attempts to deviate from the rules. Such a deviation does not always mean an innovative idea; it may naturally mean an expressly malevolent initiative to constrain 
competition. In this case we assume that the public purchaser has an interest in conducting competition in as wide a range as possible, and that she/he is authorised to take more initiatives due to professional reasons for public procurement and to boldly apply the innovative solutions enabled by legal regulations.

In the case of the nine EU Member States under study, we compare from what point of view is the court forum procurement specific. The majority opted for the standard court solution; in a few cases a mixed model is being built. It is perceptible that few Member States chose the standard route of civil law.

Table 1: Organisation responsible for the remedy decision of the first instance in the remedy system

\begin{tabular}{lcccc}
\hline \multicolumn{1}{c}{ First instance } & $\begin{array}{c}\text { Administrative } \\
\text { court }\end{array}$ & Civil court & $\begin{array}{c}\text { Independent authority, } \\
\text { chamber }\end{array}$ & Special court \\
\hline Austria & $\mathrm{x}$ & & $\mathrm{x}$ & \\
Germany & $\mathrm{x}$ & $\mathrm{x}$ & & \\
France & & & & $\mathrm{x}$ \\
Finland & $\mathrm{x}$ & & $\mathrm{x}$ & \\
Sweden & & & $\mathrm{x}$ & \\
Poland & & $\mathrm{x}$ & & \\
Romania & $\mathrm{x}$ & & $\mathrm{x}$ \\
Italy & & & \\
Hungary & & & \\
\hline
\end{tabular}

Source: Authors

Austria and France have administrative courts; in Germany there are the Chambers of Public Procurement Review, which are bodies similar to courts but are not courts themselves. In Finland, legal disputes are taken to the Market Court, which is a specialised court. In Sweden, the competition authority can be regarded as an administrative body in the sense that it does not adjudge, it only supervises. The competition authority may refer cases to the administrative courts only if they find the contracting authorities to be in violation of the rules of public procurement for imposing fines. The Swedish competition authority is a public authority, which safeguards competition, intensifies it and supervises public procurement in Sweden, focusing on the illegal direct awarding of contracts. In Poland, the body of the first instance is the National Appeals Chamber, which is a special body with an administrative nature set up by the Act on Public Procurement with exclusive powers to hear the legal disputes between economic actors and the competent authorities in the first instance and to make decisions. In Italy, the administrative court decides on issues of public procurement. In the majority of the cases under study, a court or a court-like organisation takes action in the first instance; in a lesser number of cases an administrative agency makes the decision. 
Table 2: Payment of fees upon the commencement of the remedy procedure, the application of fines as a sanction

\begin{tabular}{lc}
\hline & Remedy fee \\
\hline Austria & $x$ \\
Germany & $x$ \\
France & - \\
Finland & $x$ \\
Sweden & - \\
Poland & $x$ \\
Romania & NCSC; $x$ court \\
Italy & ANAC; $x$ court \\
Hungary & $x$ \\
\hline
\end{tabular}

Source: Authors

In the majority of the Member States under study, the legal remedy is initiated for a fee. The form in which the party winning the litigation is compensated as a result varies, if, for instance, a party lost the opportunity to perform. Since the decision of the European Court of Justice brought in the joint cases of SC Star Storage and Others v. Institutul Național de Cercetare-Dezvoltare în Informatică (C439/14 and C488/14) it is no longer disputed that the existence of an administrative service fee is in line with the directives. This, however, does not mean that the amount of the fee could be determined freely, independently of market conditions and the capability of market actors to bear costs.

In Austria, remedy fees have to be paid on the review applications (Nachprüfungsantrag) and fact-finding applications (Feststellungsantrag). The amount depends on the value of the contract and some other factors, such as the type of the procurement procedure or the type of the contract, etc. According to the rules on fees for public procurement of the Federal Administrative Court, fees between EUR 500-6,156 have to be paid to initiate the procedure.

In Germany, the amount of the fee is generally based on the value of the contract to be awarded. The minimum fee is EUR 2,500. The fee may not exceed EUR 50,000. In individual cases, if extraordinary efforts are required or the economic importance of the contract is particularly great, the fee may be raised up to EUR 100,000.

In France and in Sweden, no fees are required to be paid to initiate legal remedy.

In Finland, the basic remedy fee in the case of legal disputes concerning public procurement is EUR 2,000 (except for private individuals, whose fee is EUR 500). If the value of the awarded contract reaches EUR 1,000,000, the remedy fee rises to EUR 4,000 . If the value of the awarded contract is at least EUR 10,000,000, the remedy fee increases to EUR 6,000.

In Poland, the fee for any appeal submitted to the National Appeals Chamber (body of the first instance) varies depending on the value of the public procurement contract. In the case of values below the EU threshold the fee is PLN 7,500 (approx. 
EUR 1,744) in the case of the procurement of goods and services, and PLN 10,000 (approx. EUR 2,325) in the case of works contracts, while in the cases of contracts at or above the EU threshold the fee is PLN 15,000 (approx. EUR 3,488) for the procurement of goods and services, and PLN 20,000 (approx. EUR 4,651) for works contracts. In the case of a review, this value may increase up to PLN 100,000 (EUR 23,256).

In Romania, the procedure in front of the National Council for the Solving of Complaints (NCSC) is free of charge. This is one of the main reasons why most bidders turn to the NSCS with their complaints and not to the court. If, however, their first choice was the court, they would have to pay certain fees. The concrete value of the individual levy is determined based on an appropriate algorithm; the fee amounts to $2 \%$ of the value of the (estimated) value of the contract of the complaint but this rate is reduced from a certain value.

In Italy, the regional administrative court charges a fee of EUR 2,000-6,000, while the State Council charges a fee of EUR 3,000-9,000. In view of the fact that the court fee in the case of a simple complaint is EUR 650, it is obvious that in the case of low value contracts, economic actors prefer to turn to other types of legal remedy, such as out of court procedure in front of the anti-corruption authority.

In Hungary, the amount of the fee depends on the number of elements in the application and is 1 to $2 \%$ of the estimated value or the contract value.

The application of a public procurement fine is not at all widespread. According to Recital (14) and Articles 2d) and 2e) of Directive 2007/66/EC, invalidity is the most efficient mode of re-establishing competition and opening new business opportunities for those who were deprived of their opportunity to compete contrary to the law. An alternative to this is imposing fines or restricting the period of the contract, of which individual Member States decide on an ad hoc basis. The 2017 Report of the European Commission on the Remedies Directives (Directives 89/665/EEC and 92/13/EEC) also states that 'for alternative penalties, the majority of Member States transposed both fines and the shortening of the duration of the contracts (...) (European Commission, 2017). In particular, Member States consider that fines constitute a mere relocation of funds.' In Austria and Poland, fines are charged only exceptionally, in Germany only in cartel cases, in Finland fines are exceptional, in France the administrative court imposes fines relatively frequently, while in Sweden they are applied in about $10 \%$ of the cases; in Romania, only a court may impose a fine as an alternative to the annulment of certain decisions of the procedure hence it is fairly rarely applied. In Hungary, the success of the remedy forum is measured specifically by the revenue from fines, which should be as high as possible.

In Austria, the parties usually accept the decisions of the review bodies of the first instance, i.e. those of the administrative courts, and submit a complaint (to the Constitutional Court) or a review application (Appeals Administrative Court) in very few cases only, although the procedural and financial burden of such appeals are relatively low. From the viewpoint of the efficiency and functionality of the review system in public procurement, it is highly important that decisions are made very quickly. 
Table 3: The average duration of the remedy procedure in the first instance and the efficiency of legal remedy based on experience

\begin{tabular}{ll}
\hline & Duration of the remedy procedure in the first instance \\
\hline Austria & 42 days in case of a review application \\
Germany & $2-8.6$ months depending on the chamber \\
France & Urgent: 21 days to 80 days, normal: 6.13 months \\
\hline Finland & 8.3 months \\
Sweden & 2.4 months \\
Poland & 15 days \\
Romania & 45 days \\
Italy & 30 days \\
Hungary & 28 days \\
\hline
\end{tabular}

Source: Authors

In Germany, the review chamber examines the facts of the case ex officio. This differs from a civil court procedure. Here the principle of verification has to be applied. This means that the burden of proof is on the bidder, who has to provide an explanation. The cases below the EU threshold are particularly problematic, because the claimant bidder has to substantiate the alleged violation of the contract and it has to submit the necessary evidence. All in all, the review system for public procurement below the value limit is not particularly efficient, because the little legal remedy available has substantial disadvantages relative to the legal protection offered above the value limit. The statistics on Germany indicate that in $50 \%$ of the cases the deadline for the court to close review procedures in public procurement as required by law had to be extended over the past three years.

In France, legal remedy prior to the conclusion of the contract is fairly efficient in the case of the formalised procedures (invitation to tender, competitive dialogue, negotiated competitive procedure, etc.). The decision of the French Conseil d'Etat brought in the SMIRGEOMES case rationalised and restricted this procedure: the violation of the procedural rules, if it does not impact the position of the bidder in the competition, does not lead to the annulment of the procedure, which is important because there are many minor procedural mistakes, which have no impact on the essence of the selection process.

In Finland, the remedy system for public procurement is rather effective. The Market Court and the judges of the Supreme Administrative Court possess a wealth of knowledge on public procurement cases. The courts frequently follow the earlier decisions and precedents of the Supreme Administrative Court. Thus, the decision is foreseeable in similar cases. The decisions contain thorough justification, which prevents ungrounded complaints from being submitted. The remedy system is, however, somewhat slow.

Sweden has not specified any due dates for administrative courts to deal with cases, but the courts generally give priority to appeals submitted in public procure- 
ment cases. As a result of the legal regulations concerning public procurement fines, the Swedish competition authority carried out a follow-up study in 2015 to see what happened at the contracting authorities obligated to pay a public procurement fine. The results of the follow-up study were presented in the report Fem år med upphandlingsskadeavgift [Five years of public procurement fines]. The report reveals that nine of the ten contracting authorities obligated to pay a public procurement fine introduced changes in their organisations, for instance they altered their working methods, the distribution of work or their procurement practices. In two-thirds of the cases the changes were implemented in part or in full as a result of the court decision on imposing the public procurement fine. Almost nine of the ten contracting authorities implementing changes as a result of the decision consider the changes to be positive. Thus, the national experience on public procurement fines was that they did have an impact.

The Polish remedy system in public procurement is one of the fastest in the European Union as the duration of the procedure is 15 days from submitting the complaint to the National Appeals Chamber to the day of making the decision. The procedure is very fast, at the same time very complicated in the first instance.

In Romania, the members of the review body (NSCS) are independent experts selected fundamentally based on merit and they only evaluate cases related to the awarding procedure of public procurement contracts, in most cases their decisions are just, excellently justified as the vast majority of them are confirmed by the appeals courts. A disadvantage of the system is that because of the mandatory nature of the relevant procedural due dates and the penalties that may accompany them, sometimes the arbitrators and the judges bring their decisions rather hastily without thoroughly considering the situation presented to them.

In Italy, the higher the value of the contract, the higher the proportion of those who submit petitions for protection. At these levels, the amount of the uniform contribution and the costs of litigation lose their usual deterrent effect. In the case of high value procurements, the share of contract suspensions relative to the number of injunctions issued in the course of the interim measures is substantially lower than the average.

In Hungary, the efficiency of the remedy system is characteristically measured by the speed of decision-making, which averaged 26 days in 2017. Following the introduction of the administrative service fee and in parallel with the decline in the willingness to seek legal remedy, the controlling activity of the public procurement authority was gradually built up inducing additional legal cases under the procedures launched ex officio. The number of procedures declined, while the share of ex officio procedures increased. In this way, it is rather cumbersome to measure the efficiency and genuine added value of the system. The increase in fine revenues cannot be regarded as an indicator of the efficiency of the remedy system in European practice. 
Table 4: Other specificities characterising remedy procedures linked to the professional aspects of procurement

\begin{tabular}{lccccc}
\hline & $\begin{array}{c}\text { Resolutions } \\
\text { concerning } \\
\text { uniformity }\end{array}$ & $\begin{array}{c}\text { Remedy } \\
\text { hearing }\end{array}$ & $\begin{array}{c}\text { Being subject } \\
\text { to petition }\end{array}$ & $\begin{array}{c}\text { Role of the } \\
\text { lay element }\end{array}$ & $\begin{array}{c}\text { Mandatory legal } \\
\text { representation }\end{array}$ \\
\hline Austria & - & $\mathrm{x}$ & $\mathrm{x}$ & $\mathrm{x}$ & - \\
Germany & $\mathrm{x}$ & $\mathrm{x}$ & - & $\mathrm{x}$ & - \\
France & - & $\mathrm{x}$ & $\mathrm{x}$ & - & - \\
Finland & - & $\mathrm{x}$ & - & - & - \\
Sweden & - & & - & $\mathrm{x}$ & - \\
\hline Poland & - & $\mathrm{x}$ & $\mathrm{x}$ & - & - \\
Romania & - & $\mathrm{x}$ & $\mathrm{x}$ & - & - \\
\hline Italy & $\mathrm{x}$ & $\mathrm{x}$ & $\mathrm{x}$ & - & $\mathrm{x}$ \\
\hline Hungary & $\mathrm{x}$ & $\mathrm{x}$ & $\mathrm{x}$ & $\mathrm{x}$ & $\mathrm{x}$ \\
\hline
\end{tabular}

Source: Authors

With the exception of Hungary and Italy, the other Member States typically do not have formal procedures for the unification of the positions taken by individual courts. In Germany, there is a regulation according to which if any of the supreme courts of any Land wishes to deviate from the decision of another supreme court, then it will submit its resolution in the form of a so-called deviation proposal to the Federal Court in Karlsruhe.

In Austria, Germany and Poland, it is mandatory to have hearings with limited exceptions. In France, it is possible in principle to make a decision without a hearing, but that is very rare. In contrast, in Finland oral hearings are very rare, the decisions of the Market Court are usually based on written documentation. In Sweden, the decision depends on the initiator, hence hearings are held in the majority of cases. In Romania, hearings are held depending on the decision of NSCS, where the parties may submit written conclusions in any phase of the procedure and at times may request permission to present their arguments orally. In Italy, hearings are held and prior to the decision, the parties may submit documents (evidence) and memos prior to the hearing at the administrative court. In Hungary, the significance of the hearing is declining but upon request the remedy forum characteristically does have hearings, except for certain cases. All in all, hearings are held in the majority of the Member States under study, but it is frequent that decisions are made without a hearing in France and Finland, and the situation varies in Sweden and Romania. Legislators are primarily guided by aspects of efficiency in subjecting hearings to conditions.

In Austria, the Federal Administrative Court may bring its decisions only within the limits of the elements of the petition, but the court is not required to justify the petition. In Germany, the decision-making powers of the Public Procurement Review Chamber serves the protection of the rights of the bidders and it is not under an obligation to carry out comprehensive, general compliance examinations, but it may conduct additional investigations. In France, Poland and Italy, decision-making is bound 
by the petition. In Finland, the appeals authority may acquire evidence upon its own initiative, the remedy fora are not restricted insofar as to examine only evidence submitted by the parties; this, however, does not mean an unlimited right to extend the complaint. In Sweden, the remedy forum is authorised to extend the complaint without restrictions and to acquire additional evidence. In Romania, the decision is bound by the petition, but if the review body finds in the course of the procedure appropriate to the given complaint that there were additional irregularities beside the violation constituting the subject of the complaint, it must notify the national public procurement authority and, eventually, also the Audit Office. In Hungary, the remedy forum may extend the subject of the investigation in the course of the procedure. The possibility of the extension is not widespread, but it is an applied solution in Germany and Finland, and this is the main rule in Sweden; it can also be initiated in Romania. In other words, several legislators have addressed this possibility.

As a main rule in Austria, the decisions of the administrative courts are brought by a single judge, but the law allows decision-making in 'senates'. The senate consists of three members, a chairman and two lay members, having special expertise in public procurement. The lay judges must have experience obtained either at contracting authorities or economic actors. In Germany, the public procurement review chamber consists of a chairman, a full-time and volunteer member (juror), who need not be a lawyer. In France, the procedure in the first instance is conducted in front of a single judge as in the case of every administrative or emergency procedure conducted in front of a civil court.

In Finland, the Market Court has a quorum, if three of its members having qualifications in law are present. In Sweden, the general rule applicable to the administrative court is that a judge with legal qualifications and three lay judges adjudge the cases. In Poland, appeals are generally examined by the acting court council of the National Appeals Chamber consisting of a single member, except for situations when a court council consisting of three members examines the case because of its complexity, or because of its nature as a precedent. In Romania, complaints submitted to NSCS are evaluated by a panel consisting of three members, while complaints submitted to the tribunal are adjudged by a single judge. The members of NSCS are not judges per se, but civil servants operating in accordance with a special order, who must be experts having degrees either in economics or law. In Italy, the court consists of three administrative judges. In Hungary, decisions are made within a council consisting of three members, in which the role of the lay member as a professional commissioner having experience in the subject of procurement is important. The number of the members of the acting council is characteristically more than one. The lay member without a degree in law is frequent in the remedy cases in public procurement. Criticisms in the Member States frequently refer to the lack of involving experts. Where the remedy procedure is very fast, the involvement of experts is usually omitted.

Mandatory representation is less characteristic, particularly in the first instance. Representation is definitely understood as representation of a legal nature, particu- 
larly when representation is in front of a court. The issue does not arise sharply, because if the complexity of the regulatory environment requires it, the parties tend to appear with a representative. Specialised independent expert or legal representation is mandatory in Hungary and Italy.

To conclude our analysis in terms of the four dimensions of our research model, the following results can be formulated.

When comparing the nine countries the institutional backgrounds are different. In most of the cases a court or a court-like organisation takes action in the first instance; in a lesser number of cases an administrative agency makes the decision. The results show that the first instance bodies are typically not specialized in public procurement which does not increase trust based on professional knowledge sharing.

The remedy fee is widely accepted in the analysed EU countries, which affects the remedy activity mainly for SMEs.

The length of remedy procedures is quite high in three of the investigated countries (more than 2 months), but around 1 month in 3 countries. The problem is that the procedure itself postpones the whole public procurement procedure which affects the date of signing the contract and the execution phase as well. The direct effect of the length of the remedy procedure inevitably emerges and postpones several decisions of procurement and, therefore, might increase the probability of losing money in EU-funded projects because it suspends the procurement procedure for 1-9 months depending on the country's system.

The additional characteristics show that having a hearing is part of the procedure which offers an opportunity to stakeholders to communicate and share their thoughts within the procedure. But the role of a lay element or the mandatory legal representation is not typical and the uniform decisions in the remedy systems are not widespread either. These additional elements do not support the applicant when starting a compliance procedure.

Based on the results presented above, we distinguished two characteristic groups of countries using a measurement system:

- The professional dimension is given 1 point per country if an independent authority - a body with a better understanding of special public procurement - is responsible for remedy.

- The second dimension represents the time consumption of the process. 1 point is given per country if the procedure takes 1 month or less.

- The third dimension of the categorization is determined by the fee of legal remedy. If there is no fee on legal remedies, the system of enforcement of interests is more accessible, then the given country received 1 point.

- The fourth dimension evaluates other specificities characterising remedy procedures linked to the professional aspects of procurement. If most of the listed specificities are met, the country receives 1 point. If less than 3 of the specificities are met, the country receives none. 
Summarizing country performances in all dimensions, we found that compliance criteria are best enforced by Germany, Poland, Romania, Italy and Hungary for the four dimensions, while it is less enforced by Austria, France, Finland and Sweden.

Table 5: Comparing the results based on the four dimensions

\begin{tabular}{lccccc}
\hline & $\mathbf{1}^{\text {st }}$ dimension & $\mathbf{2}^{\text {nd }}$ dimension & $\mathbf{3}^{\text {rd }}$ dimension & $\mathbf{4}^{\text {th }}$ dimension & Total \\
\hline Austria & 0 & 0 & 0 & 1 & 1 \\
Germany & 1 & 0 & 0 & 1 & 2 \\
France & 0 & 1 & 0 & 0 & 1 \\
Finland & 0 & 0 & 0 & 0 & 0 \\
Sweden & 0 & 1 & 0 & 0 & 1 \\
Poland & 1 & 0 & 1 & 0 & 2 \\
Romania & 1 & 1 & 0 & 0 & 2 \\
Italy & 0 & 1 & 0 & 1 & 2 \\
Hungary & 1 & 0 & 0 & 1 & 2 \\
\hline
\end{tabular}

Source: Authors

Based on the findings above, it is important to conclude that if the system of public procurement organizations is developed and if the legally supported enforcement of the interests of compliance is traditionally embedded in public procurement, then the longer procedure or the more expensive legal remedy is not necessarily an obstacle. However, in the context of Central and Eastern Europe, where the history of public procurement is shorter and the risk of corruption is typically higher, conditions such as affordability, professionalism, speed - which are also considered important by the states concerned - are much more important. The distinction between the two groups does not cover a qualitative difference but rather sets different priorities when remedy systems are developed, maintained and evaluated by the respective Member States.

\section{Summary}

Public policy preferences are deeply interwoven with public procurements although they occasionally add up to internal contradictions that mutually degrade each other because of their antagonistic character such as accountability and low prices, innovativeness and established references, SME-friendliness and the quest for quality, etc. (Gellén, 2016). In the case of compliance policy within public procurements the preferences are somewhat contradicting as well: there is an obvious motivation for quick and smooth public procurement proceedings with the expectation that a fair competition would promote low prices and high quality. On the other hand, compliance issues inevitably absorb costs, time and energy that do not contribute to the content of the project, adding even the risk of partly or fully losing project funding. Such contradictions are treated by policy makes by imposing high fees or applying other bureaucratic barriers to filter out as many legal remedy seekers as possible. 
In the course of our study, we explored the characteristics which influence the decision of the applicant economic actors initiating a remedy procedure. We concluded that if the activities of the remedy fora are credible, then their decisions are known in a wide range and are accepted by the initiators, who tend to trust them. If the courts frequently approve the decisions of the contracting authorities, this does not encourage economic actors to turn to the court.

For market actors, beside the criteria of a creditworthy set of organisations, decision-makers with expertise and genuine sanctions, a good relationship with the contracting authority or a fear of not welcoming their bids in public procurement subsequently constitute important aspects. If, however, it is rare to have a lay member with expertise in the subject of procurement in the remedy system, or no hearings are held, or only the content of a given petition may be the basis of remedy, this influences the willingness to initiate the procedure. As resolutions for uniformity are rarely formalised, this is not really a criterion in well-functioning remedy systems.

While the assessment of remedy fees and fines is mixed, they certainly have a deterrent force. As the majority does not require the presence of an attorney-at-law, at most it can be stated that the presence of an attorney-at-law or an expert with knowledge of the European legal cases is recommended on account of the complicated procedural rules, which, however, greatly increases costs.

As the procedure is very long in many cases, which may give rise to substantial costs, the slowness of the procedures is one of the most important deterrents in the market. It is of primary importance for economic actors to have a decision, which is professionally substantiated at not too high costs with as little in terms of negative consequences as possible and within some foreseeable time. If any of these conditions do not exist, bidders tend not to opt for the enforcement of their rights. As there is a low number of European legal cases applicable to innovative solutions, there are even less cases on the appropriate remedy experience. Thus, the willingness to litigate is actually influenced by the risks posed by the remedy system. Accordingly, and indirectly, green evaluation criteria or preference given to fair trade products carry at least as much risk as choosing the new procedural type of the innovation partnership. Confronted with a shortage of lay members and a shortage of remedy experience, the remedy fora are unable to react flexibly, which in itself leads to an increase in the risk of fines and other sanctions as a result of the remedy procedure. A remedy system specialised in public procurement is in vain, if the contracting authority intends to introduce some kind of novelty. If innovativeness strains the flexibility of the remedy forum, even the experienced contracting authorities do not dare to be innovative, because they are worried about the risks of their decision. In addition to the penalty, the risk to the supplies arising as a result of an extended procedure, or the risk to their reputation all have an impact on the restrained behaviour of the contracting authorities. Contracting authorities tend to wait and see rather than be the first to test a Dynamic Procurement System. Accord- 
ingly, the types of non-compliance include:

- absence of trust in the preparedness and reliability of the organisations;

- fear of a costly procedure;

- fear of an exceedingly lengthy and less efficient procedure;

- uncertainty related to matters that concern the possibilities of the initiator in the course of the procedure (such as the extension of elements of the original petition or the absence of hearings).

Based on the above, a procurement-friendly set of institutions must be well prepared, have experience, and be reliable, efficient, cheap and flexible. Short of these, the willingness to initiate innovative solutions declines and economic actors tend to enforce their interests less.

Additional more detailed studies should go into what sort of an impact all these have on their innovativeness and under what conditions contracting authorities would be willing to take the initiative more and to enforce their interests better. It would be important to learn what an ideal procurement-conform remedy system and procedures in public procurement would be like, which would encourage innovativeness of contracting authorities and also of the bidders.

This article summarised existing models and enables decision makers to view the reasons of non-compliant processes in a systemic perspective. The reasons and promoting factors of non-compliance ought to be handled together in a single logical framework instead of evaluating EU Member States' practices only in the context of their particular public procurement culture.

Acknowledgements: This research was supported by NKFIH (under project K $124644)$.

\section{References:}

1. Brammer, S. and Walker, H., 'Sustainable Procurement in the Public Sector: An International Comparative Study', 2011, International fournal of Operations \& Production Management, vol. 31, no. 4, pp. 452-476.

2. Court of Justice of the European Union, Case-C439/14 and C488/14, SC Star Storage and Others v. Institutul Național de Cercetare-Dezvoltare în Informatică [Online] available at http://curia.europa.eu/juris/liste.jsf?num=C-439/14\&language=EN, accessed on September $15,2020$.

3. Directive 2007/66/EC of the European Parliament and of the Council of 11 December 2007 amending Council Directives 89/665/EEC and 92/13/EEC with regard to improving the effectiveness of review procedures concerning the award of public contracts, published in the Official Journal of the European Union no. L 335/31 from 20.12.2007.

4. Directive 2007/66/EC of the European Parliament and of the Council of 11 December 2007 amending Council Directives 89/665/EEC and 92/13/EEC with regard to improving the effectiveness of review procedures concerning the award of public contracts, published in the Official Journal of the European Union no. L 335/31 from 20.12.2007. 
5. Directive 2014/23/EU of the European Parliament and of the Council of 26 February 2014 on the award of concession contracts, published in the Official Journal of the European Union no. L 94/1 from 28.3.2014.

6. Directive 2014/23/EU of the European Parliament and of the Council of 26 February 2014 on the award of concession contracts, published in the Official Journal of the European Union no. L 94/1 from 28.3.2014.

7. Directive 2014/24/EU of the European Parliament and of the Council of 26 February 2014 on public procurement and repealing Directive 2004/18/EC, published in the Official Journal of the European Union no. L 94/65 from 28.3.2014.

8. Directive 2014/24/EU of the European Parliament and of the Council of 26 February 2014 on public procurement and repealing Directive 2004/18/EC, published in the Official Journal of the European Union no. L 94/65 from 28.3.2014.

9. Directive 2014/25/EU of the European Parliament and of the Council of 26 February 2014 on procurement by entities operating in the water, energy, transport and postal services sectors and repealing Directive 2004/17/EC, published in the Official Journal of the European Union no. L 94/243 from 28.3.2014.

10. Directive 2014/25/EU of the European Parliament and of the Council of 26 February 2014 on procurement by entities operating in the water, energy, transport and postal services sectors and repealing Directive 2004/17/EC, published in the Official Journal of the European Union no. L 94/243 from 28.3.2014.

11. European Commission, 'Report from the Commission to the European Parliament and Council on the Effectiveness of Directive 89/665/EEC and Directive 92/13/EEC, as modified by Directive 2007/66/EC, Concerning Review Procedures in the Area of Public Procurement', COM (2017) 28 final, Brussels, 24.01.2017, [Online] available at https://eur-lex. europa.eu/legal-content/EN/TXT/PDF/?uri=CELEX:52017DC0028\&from=EN, accessed on September 15, 2020.

12. European Commission, 'Report from the Commission to the European Parliament and Council on the Effectiveness of Directive 89/665/EEC and Directive 92/13/EEC, as modified by Directive 2007/66/EC, Concerning Review Procedures in the Area of Public Procurement', COM (2017) 28 final, Brussels, 24.01.2017, [Online] available at https://eur-lex. europa.eu/legal-content/EN/TXT/PDF/?uri=CELEX:52017DC0028\&from=EN, accessed on September 15, 2020.

13. Flynn, A. and Davis, P., 'The Policy - Practice Divide and SME-friendly Public Procurement', 2016, Environment and Planning C: Government and Policy, vol. 34, no. 3, pp. 559-578.

14. Flynn, A., 'Investigating the Implementation of SME-friendly Policy in Public Procurement', 2018, Policy Studies, vol. 39, no. 4, pp. 422-443.

15. French Administrative Supreme Court, SMIRGEOMES Case of 3 October 2008 (CE, 3 October 2008, SMIRGEOMES).

16. Gelderman, C.J., Ghijsen, P.W.T. and Brugman, M.J., 'Public Procurement and EU Tendering Directives - Explaining Non-Compliance', 2006, International fournal of Public Sector Management, vol. 19, no. 7, pp. 702-714.

17. Gelderman, K., Ghijsen, P. and Schoonen, J., 'Explaining Non-Compliance with European Union Procurement Directives: A Multidisciplinary Perspective', 2010, FCMS: fournal of Common Market Studies, vol. 48, no. 2, pp. 243-264. 
18. Gellén, M., 'Változatos közpolitikai célok érvényesítése egyes jogintézményekben: közbeszerzési prioritások az EU 2020 stratégia fényében' [Achieving Various Public Policy Aims by Legal Institutions: Public Porcurement Priorities in the Light of the EU 2020 Strategy], 2016, Acta Humana - Emberi Jogi Közlemények, vol. 4, no. 1, pp. 33-61.

19. Hawkins, T.G. and Muir, W.A., 'An Exploration of Knowledge-Based Factors Affecting Procurement Compliance', 2014, fournal of Public Procurement, vol. 14, no. 1, pp. 1-32.

20. Heijboer, G. and Telgen, J., 'Choosing the Open or the Restricted Procedure: A Big Deal or a Big Deal?', 2002, fournal of Public Procurement, vol. 2, no. 2, pp. 187-215.

21. Karjalainen, K., Kemppainen, K. and Van Raaij, E.M., 'Non-Compliant Work Behaviour in Purchasing: An Exploration of Reasons Behind Maverick Buying', 2009, fournal of Business Ethics, vol. 85, no. 2, pp. 245-261.

22. Kassel, D.S., 'Performance, Accountability, and the Debate Over Rules', 2008, Public Administration Review, vol. 68, no. 2, pp. 241-252.

23. Preuss, L., 'On the Contribution of Public Procurement to Entrepreneurship and Small Business Policy’ 2011, Entrepreneurship \& Regional Development, vol. 23, no. 9-10, pp. 787-814.

24. Rolfstam, M., 'Public Procurement as an Innovation Policy Tool: The Role of Institutions', 2009, Science and Public Policy, vol. 36. no. 5, pp. 349-360.

25. Testa, F., Annunziata, E., Iraldo, F. and Frey, M., 'Drawbacks and Opportunities of Green Public Procurement: An Effective Tool for Sustainable Production', 2016, fournal of Cleaner Production, vol. 112, no. 3, pp. 1893-1900.

26. Vecchiato, R. and Roveda, C., 'Foresight for Public Procurement and Regional Innovation Policy: The Case of Lombardy', 2014, Research Policy, vol. 43, no. 2, pp. 438-450. 


\section{Annex 1. \\ Interview template of the comparative study to be followed by the national experts}

1. Institutional system and independence of public procurement remedies, connection of other institutional system actors with the remedy forum.

2. Public procurement remedy fees, costs, possible opinions on the necessity and consequences of the remedy fee.

3. Data on public procurement remedies for the last 5 years, if available:

a) what entities can start the remedy process ex officio, the number of initiated procedures;

b) the number of procedures initiated by applicants;

c) the number of cases where the contracting authority's decision was annulled, in what proportion of the cases was a fine imposed;

d) in what typical cases were fines imposed and the amount of fines imposed typically.

4. Important elements of the procedural rules of appeal - deadlines in particular:

a) Is there a hearing or the decision of the appeal body is based only on the written files?

b) How long/ until what stage of the procedure can the parties submit evidence?

c) Does the remedy forum have the right of extension of the plaint, can the remedy forum examine a question that was not included in the appeal?

d) What procedural deadlines apply? Is there a distinction between certain types of cases and the procedural deadlines applicable for them?

e) Is there a public trial between legally equal parties?

f) How many members does the acting council consist of? Do you have a lay element, if yes are they involved in the investigation and do they deal with legal remedies?

g) Is the judicial remedy forum more like a public administration body or rather like a judicial court?

h) Is there mandatory representation by a registered lawyer in the appeal or in the hearing?

i) Is there a remedy (right of appeal, review right, etc.) against the decision of the $1^{\text {st }}$ instance review body?

5. Transparency of the decisions of the remedy forum(s).

6. The role of unitary decisions of a judicial remedy forum, if any.

7. Effectiveness and functionality of the remedy system.

8. The remedies in connection with the fulfillment of public contracts, in particular regarding the following issues:

a) Can a review body investigate the fulfillment of the contract?

b) Can a review forum investigate the modification of the contract?

c) Can a review body examine whether contractual sanctions are enforced by the contracting entity in the case of breaching the contract?

d) Can the review forum investigate the validity of public contracts and contract amendments, if so, what legal consequences can they impose?

9. National experiences, good and bad practices in the remedy system. 